Date submitted: 08-Mar-2011

Dates revised (if applicable): 06-Aug-2011

Accept Date: 30-Aug-2011

Manuscript Type: Original Article

Running Head: Egg yolk fatty acids

\title{
Egg yolk fatty acid profile of avian species - influence on human nutrition
}

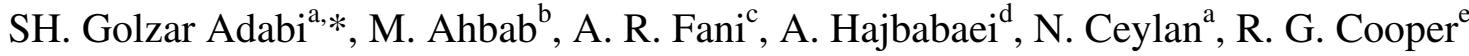

${ }^{a}$ Faculty of Agriculture, Department of Animal Science, Ankara University, Diskapi, Ankara06110-Turkey

${ }^{\mathrm{b}}$ Ostad Aali Nasab Hospital, Tabriz, Iran

${ }^{\mathrm{c}}$ Agricultural Research Institute, Tabriz, Iran

${ }^{\mathrm{d}}$ Department of Animal and Wildlife Sciences, University of Pretoria, South Africa ${ }^{\text {e}}$ Physiologist, Eurohouse, Dog Kennel Lane, Walsall, England, UK

All correspondence: phone: +90 54332546 42; e-mail: adabiishahram@gmail.com 


\section{Egg yolk fatty acid profile of avian species - influence on human nutrition}

\section{Summary}

Lipids are an important nutritional component of the avian egg. A review of the literature was completed to determine the fatty acid compositions in egg yolk from some avian species. Additionally, the nutritional influence of lipid and lipoproteins content in the plasma of male participants during 30-d feeding was discussed. The ostrich eggs had the highest unsaturated fatty acid and the lowest cholesterol content vs. other avian species. Ostrich had a higher proportion of $18: 3 \mathrm{n}-3(\mathrm{p}<0.01)$ vs. other species. Chicken yolk numerically contained much higher levels of 22:6n-3 than were found in turkeys, quails and geese but the amount of 22:6n-3 in ostrich egg was lower by comparison with species $(\mathrm{p}<0.01)$. After the storage of eggs at the room temperature, there was a notable loss of vitamin E (vitE) in the yolks of all species and this decrease was marginal $(\mathrm{p}<0.01)$ in ostrich compared with other species. There were significant $(\mathrm{p}<0.05)$ increases in plasma LDL of all male subjects. Plasma HDL decreased $(\mathrm{p}<0.05)$ only in

men that were fed chicken or ostrich eggs daily. Consumption of different species' eggs had no influence on the total male plasma cholesterol and triglyceride. LDL-C : HDL-C increased $(\mathrm{p}<0.05)$ after goose and turkey egg consumption. Consumption of one egg/mth by healthy human subjects had no effect on serum total cholesterol and triglyceride. The LDL-C:HDL-C ratio (which is a strong predictor of coronary heart disease risk) increased, although nonsignificantly, by consuming chicken, quail and ostrich egg.

Keywords: Avian species, men plasma, fatty acid, vitamin E, egg cholesterol Abridged title: Egg yolk fatty acids

\section{Introduction}

Quality of foodstuffs produced by agricultural animals becomes increasingly important with growing consumer awareness for healthy aspects of food. These aspects do not only include pathogens or traces of contaminants but also the composition of the food itself is an important characteristic of its nutritional value (Mennicken et al., 2005). The egg is composed of structures that support the developing avian embryo. Additionally, the nutritional quality of eggs for human consumption is important (Surai et al., 1999; Austic, 2008). Lipids form over $60 \%$ of the yolk's dry matter; which supports the development of the chick (Noble and Cocchi, 1990). 
The polyunsaturated fatty acyl content of current diets formulated for domestic laying birds usually consists mainly of linoleic acid (18:2n-6) with a lesser amount of $\alpha$-linolenic acid (18:3n3) (Surai et al., 1999). These two unsaturated fatty acids and their long chain derivatives are important components of animal and plant cell membranes (da Silva et al., 2009). The chicken has the ability to change a proportion of these $\mathrm{C} 18$ precursors into $\mathrm{C} 20-22$ polyunsaturates. Therefore Dietary $18: 2 n-6$ acts as the precursor of yolk $20: 4 n-6$ whereas $18: 3 n-3$ is the precursor of yolk 22:6n-3 (Surai et al., 1999; Mennicken et al., 2005).

Noble et al. (1996) carried out a comparative study on lipid composition of egg yolks from entirely wild and farmed ostriches. There were considerable differences in fatty acid profile; particularly, linolenic acid was $80 \%$ less in eggs of farmed ostriches than in eggs of wild birds. Some factors such as species, age and body fat content of the hens affects the fatty acid profile in the egg (Washburn, 1990; Scheideler et al., 1998). Moreover, this is a clear indication that there is genetic variability enabling the increase of the n-3 PUFA content or decrease the n-6:n-3 PUFA ratio in the egg yolk (Mennicken et al., 2000) for example Mennicken et al. (2005) indicated that quail are able to enrich C20:4n-6 and C22:6n-3 in the egg yolk. In other study Millet et al. (2006) examine the effect of isocaloric substitution of animal fat with NutriOmega3 FO (stabilised fish oil with standardised concentrations of C22:6n-3 (11\% of fatty acids) and C20:5n-3 (13\% of fatty acids)) on lipid profile of eggs in Araucana hens, Lohmann Selected Leghorn and ISA Brown hens. They found an association between breed and diet in yolk fatty acid content for $\mathrm{C} 18: 4 \mathrm{n}-3$ and $\mathrm{C} 22: 5 \mathrm{n}-3$ but not for other fatty acids on the other hand both dietary fat source and breed the egg yolk fatty acid profile. Egg yolk cholesterol level didn't differ by dietary fat but the effect of breed on yolk cholesterol was significant so that the Araucana eggs had significantly greater cholesterol content than the commercial hybrids ( $<<0.05$; Millet et al., 2006). Also, in Steinhilber (2005) study the effect of layer strain (but not fat source) on egg yolk cholesterol was significant. They observed that the birds with high egg production rates have lower yolk cholesterol level than the birds with low egg production rate. Both strain and dietary fatty acid composition influenced the yolk fatty acid profiles. The strains Bresse, Italian and Marans strains had a very low level of egg yolk $\alpha$-linolenic and linoleic acid, but oleic acid level was significantly high in all 3 strains. As mentioned above, lipid is the main portion of egg yolk so, it has been reported that the decrease of shelf life of the eggs during 
storage was mainly due to the lipid oxidation of egg yolk and overall reduction in egg quality (Ahn et al., 1995). Therefore, to maintain egg quality and fatty acid stability during storage, it is essential to prevent or minimize lipid oxidation (Hayat et al., 2010). $\alpha$-tocopherol, has been extensively used in feeds as a natural antioxidant which is easily deposited in the egg yolk (Chen et al., 1998; Grashorn 2005). Meluzzi et al., (2000) reported that 28 days of storage at room temperature $\left(20-25^{\circ} \mathrm{C}\right)$ did not alter the yolk fatty acid profile of Hy-Line Brown hens that fed on different doses of dl- $\alpha$-tocopheryl acetate $(0,50,100$, and $200 \mathrm{mg} / \mathrm{kg})$ and n-3 PUFA; moreover, they concluded that the levels of vitE still remained very close to those observed in fresh egg.

During the past four decades there have been many articles published concerning the egg consumption effect on the serum lipid profile of human subjects; there are, however, contradictory reports. For example, certain studies reported that egg consumption had no effect on serum concentrations of total cholesterol nor the relation between egg consumption and the risk of developing coronary heart diseases (CHD) (Kummerow et al., 1977; Flynn et al., 1979; Dawber et al., 1982; Oh and Miller, 1985; Hu et al., 1999; McNamara, 2000; Goodrow et al., 2006; Nakamura et al., 2006; Lee and Griffin, 2006). In addition other studies have shown that consuming the whole egg or an egg yolk increases blood LDL-C (Applebaum-Bowden et al., 1979; Hopkins, 1992; Clarke et al., 1997; Handelman et al., 1999; Natoli et al., 2007), HDL-C (markedly increase: Beynen and Katan, 1985; small or negligible increase: Applebaum-Bowden et al., 1979) or both of LDL-C and HDL-C (Greene et al., 2005), in addition to the risk of CHD (Weggemans et al., 2001). Mensink et al. (2003) evaluated the science to validate biomarkers linking diet and cardiovascular disease risk, and concluded that an extensive amount of research has demonstrated unequivocally that serum cholesterol is a biomarker for cardiovascular disease risk. The American Heart Association's latest nutrition recommendations do not limit the number of eggs that can be eaten, as long as one's total cholesterol intake is limited to no more than 300 milligrams per day (Kritchevsk, 2004).

Accordingly, as there are few comparative studies on the egg fatty acid content of various farm poultry species (Gallus gallus domesticus, Coturnix Coturnix Japonica; Anser anser; Meleagris gallopavo and Struthio camelus) and their influence on human serum lipid, the present study was carried out to compare the yolk fatty acid profiles of some avian species and vitE content of fresh and stored eggs ( 30 days of storage at $20 \pm 2^{\circ} \mathrm{C}$ temperature); on the other hand there have been 
few comparative studies on the relationship between different avian species eggs consumption and the cholesterol, triglyceride and lipoprotein level in humans population, so in the present study we also evaluated this effect.

\section{Materials and Methods}

\section{Trail}

Mature female birds, chickens (Leghorn; Gallus gallus domesticus), quails (Japanese quail; Coturnix Coturnix Japonica), geese (white strain; Anser anser), turkeys (Iranian native strain; Meleagris gallopavo) and ostriches (Black neck strain; Struthio camelus) were fed a corn-soy based diet formulated for each species based on their own requirement. All diets contained the same concentration of vitE premix. The diets were formulated to meet minimum nutrient requirements of each species except ostrich, as established by the National Research Council (NRC, 1994). As there is no specific reference about the ostrich nutrition requirements and as the complementary researches in the world are still under consideration so we used some references for ostrich diet formulation (Cilliers et al., 1994; Cilliers et al., 1997; Cilliers, 2004; Cooper et al., 2004). Dietary compositions are shown in Table 1. Chickens (commercial farm) and quails (East Azarbaijan Animal Science Research Centre, Bonab-Iran) were housed in 15 battery cages ( 3 and 12 chicken and quail respectively per cage) at $22-24^{\circ} \mathrm{C}$. Geese (East Azarbaijan Animal Science Research Center, Malekan-Iran) and turkeys (East Azarbaijan Animal Science Research Center, Tatar-Iran) were kept in rooms containing individual pens (15 wood shavings litter pen 3 birds each one). All birds except ostrich received $16 \mathrm{~L}$ (light) : 8D (dark) at the egg production phase. 5-year-old ostriches (Ratite Research and Development Institute, Tehran-Iran) were kept in 15 out-door units with shelter comprising 2 hens and 1 cock. For determination of cholesterol and fatty acid composition, eggs were gathered from the birds at the middle of their egg production period. The eggs were weighed, and then the egg yolk was separated from the albumen with an egg separator and then carefully rolled on a damp paper towel to remove any adhering albumen. The chalazae were also removed of yolk before weighing the yolk (Golzar Adabi et al., 2006). The total fat of diets and yolks was extracted according to Folch et al. (1957) and methylated with 5\% boron trifluoride methanol complex in methanolic solution. The lipid profile was determined by means of gas chromatography equipped with a BPX70 capillary column (SGE capillary column; length, $30 \mathrm{~m}$; I.D., $0.33 \mathrm{~mm} ; 70 \%$ cyanopropyl 
polysilphenylene-siloxane stationary phase) film, and a flame ionization detector. The operating conditions of the gas chromatograph were as follows: the initial temperature was $170^{\circ} \mathrm{C}$ for 8 min, increasing by $3{ }^{\circ} \mathrm{C} / \mathrm{min}$ to $180^{\circ} \mathrm{C}$, the temperature was increased by $5^{\circ} \mathrm{C} \min ^{-1}$ to $190^{\circ} \mathrm{C}$ and remained stable at final temperature for $25 \mathrm{~min}$, the injection temperature was $220^{\circ} \mathrm{C}$ and make up was $15 \mu \mathrm{l} / \mathrm{S}$. The FA percentage was integrated and then calculated by means of direct normalization of the peak areas. Each FA was identified in the form of a methyl ester by comparing the retention times with the standard acquired at Sigma Interlab A.S ${ }^{1}$. The concentration of egg yolk cholesterol was determined by using commercial kits (Ziestchem diagnostics Tehran, Iran). For determining egg cholesterol the yolk samples $(1 \mathrm{ml})$ were mixed with 0.05 molar of $\mathrm{NaOH}(25 \mathrm{ml})$, neutralized with 0.25 normal of $\mathrm{HCl}$, and then assayed (Luhman et al., 1990; Golzar Adabi et al., 2006). VitE content of egg yolk was determined based on Meluzzi et al. (2000).

\section{Human trail}

The effect of daily intake of above mentioned different species' eggs on serum cholesterol, triglycerides and lipoproteins was investigated in 4 men per treatment with a mean age of 55 years old (range: 50-62 years old) who were currently not taking cholesterol-lowering medication and had an average waist circumference of $87 \pm 6.8 \mathrm{~cm}$, and average body weight $79 \pm$ $6.5 \mathrm{~kg}$ with light clothes and bare feet. There were no dropouts during the study. The subjects were non-smokers and were not using any medication. Persons with a history of active small bowel disease or resection, atrophic gastritis, insulin requiring diabetes, alcoholism, pancreatic disease, or bleeding disorders were excluded from the study. Eligible male participants were randomly assigned to consume one egg in their daily diet for 30-d and during the experiment subjects were instructed to continue to consume their regular diet but to abstain from consuming eggs and egg products outside of those provided by the study (Greene et al., 2006; Golzar Adabi et al., 2010). The blood lipids in all subjects were determined at the commencement of the study in order to avoid subjective differences amongst blood lipids. In order to feed the subjects with the same level of egg yolk and albumen but considering the differences between weight of various poultry species' eggs, we decided to separate and weigh the yolk and albumen of egg after hard boiling and then the same weight of chicken yolk and albumen was prepared from 
other species' eggs. Chicken egg consists of 60 and $28 \%$ albumen and yolk, respectively (Mine, 2008). Therefore in Jumbo size fresh chicken egg with $75 \mathrm{~g}$ weight the amount of albumen and yolk are almost 45 and $21 \mathrm{~g}$ respectively.

Blood samples collected 1 week prior to supplementation. In addition, blood samples (morning blood samples were collected after an 8 hours fasting) were collected at the end of this period (Golzar Adabi et al., 2010). The effect of a feeding eggs of different species (one egg per day for 30-d as same weight as Jumbo Leghorn egg) on the total cholesterol (TC), low density lipoprotein cholesterol (LDL-C), high density lipoprotein cholesterol (HDL-C) and triglycerides (TG) concentrations and LDL-C:HDL-C ratio were examined. TC was determined by enzymatic methods (Allain et al., 1974), and HDL-C was measured in the supernatant after precipitation of apo-B-containing lipoproteins (Warnick et al., 1982). TG concentrations were determined using Roche-Diagnostics kits, which adjust for free glycerol (Carr et al., 1993). LDL-C was determined using the Friedewald equation [LDL-C = total cholesterol - HDL-C (triglycerides/5)] (Friedewald, 1972). The experimentation procedure was performed in accordance with Biosecurity Rules of Iran Agricultural Ministry and The National Committee for Ethics in Science and Technology.

\subsection{Statistical analyses}

The data yolk cholesterol, fatty acid and vitE content of egg analyzed by general linear model and plasma TC, TG, HDL, LDL and LDL-C:HDL-C ratio of the participants were analyzed by mixed models procedure of SAS software (SAS institute 1986, SAS Institute Inc., Cary, NC, USA). All percentage data were subjected to arcsin square root transformation (Steel and Torrie, 1960). All data were presented as mean $\pm \mathrm{SD}$. When necessary mean separation was accomplished by using Duncan's multiple-range test (Duncan, 1955) a probability p-value of less than 0.01 and 0.05 was considered significant.

\section{Results}

The fatty acid compositions of the yolk lipids were affected by the species (Table 2) so that there were no differences in myristic, eicosapentaenoic, docosapentaenoic acid and n-3 PUFA content of different species. Of course eicosapentaenoic acid did not detect in chicken, quail and turkey eggs (Table 2). The concentration of saturated fatty acids was affected only by species for palmitic and stearic acid, indicating that the significantly lowest $(\mathrm{p}<0.01)$ concentrations were 
seen for ostrich and the highest $(\mathrm{p}<0.05)$ concentrations occurred for ostrich and chicken, respectively. Ostrich egg had the highest $(\mathrm{p}<0.01)$ oleic acid $(\mathrm{C} 18: 1 \mathrm{n}-9)$ in contrast to the turkey egg had the highest $(\mathrm{p}<0.05)$ vaccenic acid $(\mathrm{C} 18: 1 \mathrm{n}-7)$ (Table 2$)$. The fatty acid profile of quail egg was very similar to that of the chicken egg (Table 2). Major findings in PUFA level of eggs were that the proportion of linolenic and arachidonic acids were higher $(\mathrm{p}<0.01)$ in the yolk of the ostrich egg than in the yolk of the other species. Only do docosahexaenoic fatty acid was the lowest $(\mathrm{p}<0.01)$ in the yolk of the ostrich eggs. It should be mentioned that linolenic acid is the predominate $\mathrm{n}-3$ fatty acid in ostrich egg $(\mathrm{p}<0.01)$. On the other hand, the predominant $\mathrm{n}-6$ fatty acid was linoleic with the highest level in chicken and ostrich eggs $(\mathrm{p}<0.05)$.

The n-6:n-3 fatty acid ratio of eggs ranged from 15 to 19 . The geese eggs had the lowest ratio at $15.62 \pm 1.04(\mathrm{p}<0.01$; Table 2). Other differences were also found in the current study; for example, the ostrich egg lipid contained the highest level of total monounsaturated fatty acids (the sum of the oleic and vaccenic acid) $(\mathrm{p}<0.05)$ and total PUFA (the sum of the linoleic, linolenic, arachidonic, eicosapentaenoic, docosapentaenoic and docosahexaenoic) ( $<<0.01$; Table $2)$. The yolk cholesterol levels were significantly lower $(\mathrm{p}<0.05)$ in the ostrich egg $\left(9.75 \mathrm{mg} \mathrm{g}^{-1}\right.$ of yolk) than those in the other species. The cholesterol concentration of the quail (Corturnix coturnix Japonica) egg was very similar to that of the chicken egg in terms of $\mathrm{mg} \mathrm{g}^{-1}$ of yolk (Table 3). This finding is in agreement with Bragagnolo and Rodriguez-Amaya (2003) who demonstrated that the cholesterol content of the quail egg in $\mathrm{mg} \mathrm{g}^{-1}$ of yolk was very similar to that of the chicken egg and reported that the overall average of the cholesterol content was 12.0 and $12.1 \mathrm{mg} \cdot \mathrm{g}^{-1}$ of chicken and quail egg yolk, respectively.

The proportion of vitE in both fresh and stored eggs are shown in Figure $1 \& 2$. The fresh eggs of chicken, quail and turkey contained the same proportion of vitE by comparison with the other two species. The concentration of plasma LDL-C after the egg period in subjects varied when compare with the baseline data so that, when all data related to before and after egg feeding period were evaluated, there were significant $(\mathrm{p}<0.05$; Table 4$)$ increases in LDL-C at the end of egg period in all treatments. Plasma HDL-C decreased ( $\mathrm{p}<0.05$; Table 4) only in subjects that received chicken or ostrich eggs daily. At the end of the egg period LDL-C:HDL-C increased $(\mathrm{p}<0.05$; Table 4$)$ in men fed goose or turkey egg.

\section{Discussion}


The successful development of the embryo is dependent upon the presence of both n- 6 and n-3 polyunsaturates in the yolk lipids in amounts and proportions which are appropriate to meet the demands of the various embryonic tissues (Speake et al., 1999). On the other hand it has previously been shown that the PUFA profile of the yolk is highly dependent on the types of the PUFAs present in the birds' diets (Hargis and Van Elswyk, 1993; Farrell, 1998; Ayerza and Coates, 2000; da Silva et al., 2009). Di Meo et al. (2003) investigated the physical and chemical quality of ostrich eggs during the laying season and reported that compared with the chicken's egg, the ostrich egg has similar chemical and nutritive characteristics, but a higher unsaturated : saturated fatty acid ratio, and lower cholesterol content.

The mean cholesterol content of chicken yolk (12-19 $\mathrm{mg} \mathrm{g}^{-1}$; Reiner et al., 1995; Bragagnolo and Rodriguez-Amaya, 2003); ostrich (ca. $10.8 \mathrm{mg} \mathrm{g}^{-1}$ of yolk; Di Meo et al., 2003; Meluzzi et al., 1995), quail (8.5-10.9 $\mathrm{mg} \mathrm{g}^{-1}$ of yolk; da Silva et al., 2009); hard boiled goose egg (15.8-17.5 mg $\mathrm{g}^{-1}$ of yolk for white and African goose respectively; Bair and Marion, 1978); and turkey (16.818. $1 \mathrm{mg} \mathrm{g}^{-1}$ for domestic and wild turkey respectively; Maurice et al., 1994) were reported. The cholesterol level in eggs from different species varies with breed, age of the hen, egg and yolk weight and diet (Bragagnolo and Rodriguez-Amaya, 2003). Even, Chavous et al. (1965) tested the genetic variation in egg yolk cholesterol and found a significant difference between 20 breeding combinations of commercial laying hens.

The n-6:n-3 fatty acid ratio of egg yolks of the current investigation is higher compared with the some of the other trials (da Silva Filardi et al., 2005; Kralik et al., 2008; Ceylan et al., 2011). In this regard we did no inclusion of vegetable oil in the experimental diets and the large part of diet consisted of corn which is rich in linoleic acid (18: 2n-6) (Baur Jr and Brown, 1945; Guclu et al., 2008; Kamal and Klein, 2007) (Table 1). The high proportion above-mentioned compare vs. other studies can be related to diet composition; because fatty acid profile of the diets have major effect on yolk fatty acid composition in different poultry species (Gulcu et al., 2008; Oliveira et al., 2010; Ceylan et al., 2011). In Milinsk et al. (2003) study the amount of n-6:n-3 fatty acid ratio of yolk after 16 weeks feeding by sunflower oil (which is an important source of $n-6$ ) was 17.7 and $12.0 \%$ in Red Lohman and White Lohman hens, respectively. In other study the n-6:n3 ratio of the egg was reported 27.3, 28.9 and 39.2 for regular white-shelled eggs, certified organic free-range brown eggs and naturally nested, uncaged hens fed diets with no steroids or 
no stimulants, respectively (Cherian et al., 2002). On the other hand the dietary patterns of the birds are different so that Klasing (1998) classified the birds according to a variety of feed consumption schemes. As it is shown in table 1 for example chicken and quail diet is consisted of grains and seeds which are rich in 18: 2n-6 but goose, turkey and especially ostrich diet has different levels of grass with a great amount of galactolipids which 60 to $90 \%$ of their whole fatty acids are 18: 3n-3 (Speake et al., 1999).

Jiang et al. (1994) supplemented the feed with $200 \mathrm{mg}$ vitE. $\mathrm{kg}^{-1}$. The $\alpha$-tocopherol concentrations

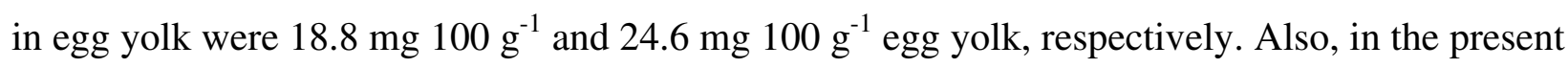
investigation, the changes in the vitE content of eggs after the 30-d storage are illustrated (Figure 2). Thereafter, the vitE content attenuated by 10 to $12 \%$. In the study of Meluzzi et al. (2000) after 28-d of storage, the levels of vitE remained still very close to those observed in fresh eggs, suggesting that the vitamin was not used to prevent lipid oxidation in the yolk. In other studies, however, storage of eggs led to marked reductions in egg $\alpha$-tocopherol $(p<0.05)$ (Grune et al., 2001; Hayat et al., 2010). The effect of dietary $\alpha$ - tocopheryl acetate supplementation on enhancing lipid stability in egg yolk has been previously reported (Chen and Hsu, 2006; Bourre and Galea, 2006). Nevertheless, earlier studies suggested that altering the tocopherol content of eggs is dependent upon the stage of life cycle, agronomic and genetic factors, season, weather, harvesting methods, processing procedures, storage environment, and time periods of storage (Bauernfeind and Desai, 1977).

Another part of the present study investigated the effect of various species eggs on men plasma lipid and lipoprotein. Our results, such as some other clinical studies showed that the egg consumption and serum cholesterol concentrations are not directly related (Chenoweth et al., 1981; Vorster et al., 1992; Ginsberg et al., 1994; Hu et al., 1999; Kerver et al., 2002; Chen and Watson, 2002; Djoussé and Gaziano, 2008). One hundred and sixteen male candidates aged 3262 years-old consumed two whole fresh eggs daily in their regular diets for 3 months and also eliminated eggs from their diets for a further 3 months. No significant increase in mean serum cholesterol was found, nor was there a significant association of dietary cholesterol intake with serum cholesterol (Flynn et al., 1979).

Cholesterol is mostly circulated in the liver in the form of LDL-C. Liver cells LDL-C receptors actively take up the LDL-C for metabolism. Other extra-hepatic tissues also contain LDL-C 
receptors that are not as active as the liver cell receptors. Thus, the plasma concentration of LDL$\mathrm{C}$ is greatly affected by the rate at which LDL-C is formed and the rate of uptake by LDL-C receptors. Therefore, genetics plays a role here by determining the rate of activity of LDL-C receptors (Vaghefi, 2002). In controlled metabolic studies, ingestion of cholesterol by eating egg yolks or whole eggs raises the serum LDL-C level (Hopkins, 1992; Clarke et al., 1999). On the other hand, the effects of egg consumption on raising HDL levels have been observed in some studies (Schnohr, 1994) but some studies also reported no particular effects (Ginsberg et al., 1994). In a study conducted by Greene et al. (2005) it was shown that both plasma LDL-C and HDL-C significantly $(\mathrm{p}<0.05)$ increased in men/women aged $29-60 \mathrm{yr}$. by consuming 3 eggs/d, and there were no significant alterations in the ratios of LDL-C:HDL-C. In an investigation by Goodrow et al. (2006) the study serum concentrations of TC, LDL-C, HDL-C and TG were not affected by consuming $1 \mathrm{egg} / \mathrm{d}$ for $5 \mathrm{wk}$ in men and women $>60 \mathrm{yr}$. old. Zanni et al. (1987) suggested that diet cholesterol has no effect on plasma TG levels; on the other hand in the Framingham study and some other researches no relation was found between TC levels, resulting from increased egg consumption, and the incidence of CHD (Dawber et al., 1982; Gramenzi et al., 1990; Greene et al., 2005). The ratio of LDL-C:HDL-C is a strong predictor of CHD risk, so changes in both variables will produce changes in this ratio. It is necessary mentioned that a wide variability in individual response to dietary cholesterol (hyperresponders $v s$. hyporesponders) has been reported. It has been suggested that among hyper-responders, the dietary cholesterol from eggs leads to a modest increase in serum LDL and HDL cholesterol and no effect on LDL/HDL ratio (Djoussé and Gaziano, 2008). Chen and Watson (2002) reported that the relationship between egg intake, serum cholesterol, and coronary heart disease are inconsistent. These conflicting results could be attributed to other extraneous factors. For example some of the conflicting results originate from poor design and/or some of them are due to individual differences in the sensitivity of serum cholesterol dietary intake.

Recently Kayikcioglu and Soydan (2009) reviewed egg consumption and cardiovascular health. They discussed that it is not possible to standardize consumption of other dietary sources of cholesterol and saturated/unsaturated fatty acids, carbohydrates and antioxidant vitamins between the groups based only on the comparison of egg consumption. As a result, this reality should be taken into consideration when interpreting the results of these studies. A difference 
between our study and the results of Goodrow et al. (2006) about the serum LDL-C, may be related to the greater age of the subjects that participated in the study (mean age: 79 yr.; range: 60-96 yr.). Indeed, there are several studies (Garry et al., 1992; Ferrara et al., 1997) which suggest that serum LDL-C concentrations are attenuated in older populations.

\section{Conclusion}

There are a variety of articles on the avian species differences in the fatty acid profile and the cholesterol content of the yolk, and the effect of egg consumption on human subject's blood lipid and lipoprotein concentrations. Yet, it appears that the current investigation is the first to report the effect of consumption of eggs of different species (one egg/day for 30-d) on the lipid and lipoprotein status of the plasma in male participants. Our study demonstrated that:

1) Cholesterol and lipid content of the eggs vary among different avian species. The chicken (Leghorn) and quail (Japanese quail) have the same amount of the cholesterol based on mg.g ${ }^{-1}$ of yolk.

2) The egg yolk fatty acid profiles of different avian species vary, e.g. the ostrich egg has significantly $(\mathrm{p}<0.01)$ higher and lower amounts of 18:3n-3 and 22:6n-3, respectively.

3) The egg yolk vitE level is attenuated (based on $\mu \mathrm{g} \mathrm{g}^{-1}$ of yolk) following 30-d storage at $20 \pm 2^{\circ} \mathrm{C}$ temperature It decreases in the ostrich egg yolk, and is minimal in other species.

4) Consuming one egg/d for 30-d (ca. same weight as Jumbo size fresh leghorn egg with 75 $\mathrm{g}$ weight) increased the LDL-C level in all groups, decreased the HDL-C in the chicken and ostrich group, and increased the LDL:HDL ratio in groups that received goose and turkey eggs.

5) In the present study chicken eggs showed no effect on the LDL:HDL ratio but it is worth noting that, in advance, in order to reduce egg intake especially in the healthy person, it is preferred to assess benefits and disadvantages of individual egg consumption.

\section{Conflict of interest}

Authors have no conflicts of interest to declare whatsoever.

\section{Acknowledgements}

We gratefully acknowledge the assistance of Mr.'s S. Azarfar, R. Pourhasan and H. Hamidiyan in Agricultural Research Center for the care of the experimental birds and for the egg collection. 
In addition, Miss E. Golzar Adabi (Goldis Educational Institute, Tabriz-Iran) provided translation assistance.

\section{References}

Ahn, D. U.; Sunwoo, H. H.; Wolfe, F. H.; Sim, J. S., 1995: Effects of dietary linolenic acid and strain of hen on the fatty acid composition, storage stability and flavor characteristics of chicken eggs. Poultry Science 74, 1540-1547.

Allain, C. C.; Poon, L. S.; Chan, C. S.; Richmond, W.; Fu, P. C., 1974: Enzymatic determination of total serum cholesterol. Clinical Chemistry 20, 470-475.

Applebaum-Bowden, D.; Hazzard, W. R.; Cain, J.; Cheung, M. C.; Kushwaha, R. S.; Albers. J. J., 1979: Short-term egg yolk feeding in humans. Increase in apolipoprotein B and low density lipoprotein cholesterol. Atherosclerosis 33, 385-396.

Austic, R.E., 2008: Eggs: Composition and Structure. Encyclopedia of Animal Science 1, 1-4.

Ayerza, R.; Coates, W., 2000: Dietary levels of chia: Influence on yolk cholesterol, lipid content and fatty acid composition for two strains of hens. Poultry Science 79, 724-739.

Bair, C. W.; Marion, W. W., 1978: Yolk cholesterol in eggs from various avian species. Poultry Science 57, 1260-1265.

Bauernfeind, J. C.; Desai, I. D., 1977: The tocopherol content of food and influencing factors. CRC Critical Reviews in Food Science and Nutrition 8, 337-382.

Baur Jr, F. J.; Brown, J. B., 1945: The fatty acids of corn oil. Journal of the American Chemical Society 67 (11), 1899-1900.

Beynen, A. C.; Katan, M. B., 1985: Effect of egg yolk feeding on the concentration and composition of serum lipoproteins in man. Atherosclerosis 54 (2), 157-166.

Bourre, J. M.; Galea, F., 2006: An important source of omega-fatty acids, vitamins D and E, carotenoids, iodine and selenium: A new natural multi-enriched egg. The Journal of Nutrition Health and Aging 10, 371-376.

Bragagnolo, N.; Rodriguez-Amaya, D. B., 2003: Comparison of the cholesterol content of Brazilian chicken and quail eggs. Journal of Food Composition and Analysis 16, 147-153. Carr, T. P.; Andresen, C. J.; Rudel, L. L., 1993: Enzymatic determination of triglyceride, free cholesterol, and total cholesterol in tissue lipid extracts. Clinical Biochemistry 26, 39-42. 
Ceylan, N.; Ciftci, I.; Mizrak, C.; Kahraman, Z.; Efil, H., 2011: Influence of different dietary oil sources on performance and fatty acid profile of egg yolk in laying hens. Journal of Animal and Feed Sciences 20, 71-83.

Chavous, L. G.; Mc Clung, M. R.; Gardiner, E. E., 1965: Genetic variations among breeding combinations in egg yolk cholesterol. Poultry Science 44, 1359-1364.

Chen, Y.; Watson, R. R., 2002: Effect of dietary eggs on human serum cholesterol and coronary heart disease. In: Watson, R. R. (ed.), Eggs and Health Promotion. Blackwell Publishing, Iowa, USA. 101-109.

Chen, J. Y.; Latshaw, J. D.; Lee, H. O.; Min, D. B., 1998: $\alpha$-tocopherol content and oxidative stability of egg yolk as related to dietary a-tocopherol. Journal of Food Science 63, 919-922.

Chen, T. F.; Hsu, J. C., 2006: Incorporation of vitamin E into n-3 polyunsaturated fatty acids enriched duck eggs. Symposium COA/INRA Scientific Cooperation in Agriculture, November 7-10. pp. 217-220.

Chenoweth,W.; Ullmann, M.; Simpson, R.; Leveille, G., 1981: Influence of dietary cholesterol and fat on serum lipids in men. Journal of Nutrition 111(12), 2069-2080.

Cherian, G.; Holsonbake, T. B.; Goeger, M. P., 2002: Fatty acid composition and egg components of specialty eggs. Poultry Science 81, 30-33.

Cilliers, S. C.; Hayes, J. P.; Maritz, J. S.; Chwalibog, A.; Du Preez, J. J., 1994: True and apparent metabolisable energy values of lucerne and yellow maize in adult roosters and mature ostriches (Struthio camelus). Animal Production 59, 309-313.

Cilliers, S. C.; Hayes, J. P.; Chwalibog, A.; Du Preez, J. J.; Sales, J., 1997: A comparative study between mature ostriches(Struthio camelus) and adult cockerels with respect to true and apparent metabolisable energy values for maize, barley, oats and triticale. British Poultry Science 38, 96-100.

Cilliers, F., 2004: Husbandry and nutritional practices in chick rearing. Proceedings of the $11^{\text {th }}$ Ostrich World Congress, Island Great Brijun, Croatia.

Clarke, R.; Frost, C.; Collins, R.; Appleby, P.; Peto, R., 1997: Dietary lipids and blood cholesterol: quantitative meta-analysis of metabolic ward studies. British Medical Journal 314, $112-117$. 
Cooper, R. G.; Horbanczuk, J. O.; Fujihara, N., 2004: Nutrition and feed management in the ostrich (Struthio camelus var. domesticus). Animal Science Journal 75, 175-181.

da Silva Filardi, R.; Junqueira, O. M.; de Laurentiz, A. C.; Casartelli, E. M.; Aparecida Rodrigues, E.; Francelino Araujo, L., 2005: Influence of different fat sources on the performance, egg quality, and lipid profile of egg yolks of commercial layers in the second laying cycle. Journal of Applied Poultry Research 14, 258-264.

da Silva, W. A.; Elias A. H. N.; Aricetti, J. A.; Sakamoto, M. I.; Murakami, A. E.; Gomes, S. T. M.; Visentainer, J. V.; de Souza, N. E.; Matsushita, M., 2009: Quail egg yolk (Coturnix coturnix japonica) enriched with omega-3 fatty acids. Food Science and Technology 42 , 660-663.

Dawber, T. R.; Nickerson, R. J.; Brand, F. N.; Pool, J., 1982: Eggs, serum cholesterol, and coronary heart disease. The American Journal of Clinical Nutrition 36, 617-625.

Di Meo, C.; Stanco. G.; Cutrignelli, M. I.; Castaldo, S.; Nizza, A., 2003: Physical and chemical quality of ostrich eggs during the laying season. British Poultry Science 44, 386-390.

Djoussé, L.; Gaziano, J. M., 2008: Egg consumption and risk of heart failure in the physicians' health study. Circulation 117, 512-516.

Duncan, D. B., 1955: Multiple range and multiple F tests. Biometrics 11, 1-42.

Farrell, D. J., 1998: Enrichment of hen eggs within n-3 long-chain fatty acids and evaluation of enriched eggs in humans. The American Journal of Clinical Nutrition 68, 538-544.

Ferrara, A.; Barrett-Connor, E.; Shan, J., 1997: Total LDL, and HDL cholesterol decrease with age in older men and women. Circulation 96, 37-43.

Flynn, M. A.; Nolph, G. B.; Flynn, T. C.; Kahrs, R.; Krause, G., 1979: Effect of dietary egg on human serum cholesterol and triglycerides. The American Journal of Clinical Nutrition 32(5), 1051-1057.

Folch, J.; Lees, M.; Sloane Stanley, G. H., 1957: A simple method for the isolation and purification of total lipids from animal tissues. The Journal of Biological Chemistry 226, 497-509.

Friedewald, W. T.; Levy, R. I.; Fredrickson, D. S., 1972: Estimation of the concentration of lowdensity lipoprotein cholesterol in plasma, without use of the preparative ultracentrifuge. Clinical Chemistry 18, 499-502. 
Garry, P. J.; Hunt, W. C.; Koehler, K. M.; Vander Jagt, D. J.; Vellas, B. J., 1992: Longitudinal study of dietary intakes and plasma lipids in healthy elderly men and women. The American Journal of Clinical Nutrition 55, 682-688.

Garwin, J. L.; Morgan, J. M.; Stowell, R. L.; Richardson, M. P.; Walker, M. C.; Capuzzi, D. M., 1992: Modified eggs are compatible with a diet that reduces serum cholesterol concentrations in humans. Journal of Nutrition 122, 2153-2160.

Ginsberg, H. H.; Karnally, W.; Siddiqyi, M.; Holleran, S.; Tall, A. R.; Ramsey, S. C.; Deckelbaum, R. J.; Blaner, W. S.; Ramakrishnan, R., 1994: A dose-response study of the effects of dietary cholesterol on fasting and postprandial lipid and lipoprotein metabolism in healthy young men. Arteriosclerosis, Thrombosis and Vascular Biology 14, 576-586.

Golzar Aadabi, SH.; Moghaddam, G.; Taghizadeh, A.; Nematollahi, A.; Farahvash, T., 2006: Effect of L-Carnitine and vegetable fat on broiler breeder fertility, hatchability, egg yolk and serum cholesterol and triglyceride. International Journal of Poultry Science 5, 970-974.

Golzar Adabi, SH.; Farahvash, T.; Ceylan, N.; Noumi, S.; Davoudi, J., 2008: Enrichment of eggs with Omega-3 polyunsaturated fatty acids and effects of L-carnitine supplementation. International Symposium on The Return of The Good Egg. Istanbul-Turkey, November, pp. 26-28.

Golzar Adabi, SH.; Kamali, M. A.; Davoudi, J.; Cooper, R. G.; Hajbabaei, A., 2010: Quantification of lutein in egg following feeding hens with a lutein supplement and quantification of lutein in human plasma after consumption of lutein enriched eggs. Archiv Fur Geflügelkunde 74, 158-163.

Goodrow, E. F.; Wilson, T. A.; Houde, S. C.; Vishwanathan, R.; Scollin, P. A.; Handelman, G.; Nicolosi, R. J., 2006: Consumption of one egg per day increases serum lutein and zeaxanthin concentrations in older adults without altering serum lipid and lipoprotein cholesterol concentrations. Journal of Nutrition 136, 2519-2524.

Gramenzi, A.; Gentile, A.; Fasoli, M.; Negri, E.; Parazzini, F.; La Vecchia, C., 1990: Association between certain foods and risk of acute myocardial infarction in women. British Medical Journal 300, 771-773. 
Grashorn, M.A., 2005: Enrichment of eggs and poultry meat with biologically active substances by feed modifications and effects on the final quality of the product. Polish Journal of Food and Nutrition Sciences 14, 15-20.

Greene, C. M.; Zern, T. L.; Wood, R. J.; Shrestha, S.; Aggarwal, D.; Sharman, M. J.; Volek, J. S.; Fernandez, M. L., 2005: Maintenance of the LDL cholesterol : HDL cholesterol ratio in an elderly population given a dietary cholesterol challenge. Journal of Nutrition 135, 27932798.

Greene, C. M.; Waters, D.; Clark, R. M.; Contois, J. H.; Fernandez, M. L., 2006: Plasma LDL and HDL characteristics and carotenoid content are positively influenced by egg consumption in an elderly population. Nutrition and Metabolism 3, 6 .

Grune, T.; Kramer, K.; Hoppe, P. P.; Siems, W., 2001: Enrichment of eggs with n-3 polyunsaturated fatty acids: effects of vitamin E supplementation. Lipids 36, 833-838.

Guclu, B.K.; Uyanik, F.; Iscan, K. M., 2008: Effects of dietary oil sources on egg quality, fatty acid composition of eggs and blood lipids in laying quail. South African Journal of Animal Science 38 (2), 91-100.

Handelman, G.J.; Nightingale, Z.D.; Lichtenstein, A.H.; Schaefer, E.J.; Blumberg, J.B., 1999: Lutein and zeaxanthin concentrations in plasma after dietary supplementation with egg yolk. American Journal of Clinical Nutrition 70, 247-51.

Hargis, P. S.; Van Elswyk, M. E., 1993: Manipulating the fatty acid composition of poultry meat and eggs for the health conscious consumer. World Poultry Science Journal 49, 251-264.

Hayat, Z.; Cherian, G.; Pasha, T. N.; Khattak, F. M.; Jabbar, M. A., 2010: Oxidative stability and lipid components of eggs from flax-fed hens: effect of dietary antioxidants and storage. Poultry Science 89, 1285-1292.

Hopkins, P. N., 1992: Effects of dietary cholesterol on serum cholesterol: a meta-analysis and review. The American Journal of Clinical Nutrition 55, 1060-1070.

Hu, F. B.; Stampfer, M. J.; Rimm, E. B.; Manson, J. E.; Ascherio, A.; Colditz, G. A.; Rosner, B. A.; Spiegelman, D.; Speizer, F. E.; Sacks, F. M.; Hennekens, C. H.; Willett, W. C., 1999: A prospective study of egg consumption and risk of cardiovascular disease in men and women. Journal of the American Medical Association 281, 1387-1394. 
Jiang, Y. H.; McGeachin, R. B.; Bailey, C. A., 1994: Alpha-Tocopherol, beta-carotene, and retinol enrichment of chicken eggs. Poultry Science 73, 1137-1143.

Kamal, M. A.; Klein, P., 2007: Estimation of fatty acids in corn oil by Gas Capillary ChromatographySaudi. Journal of Biological Sciences 14 (1), 17-20.

Kayikcioglu, M.; Soydan, I., 2009: Egg consumption and cardiovascular health. Archive of the Turkish Society of Cardiology 37(5), 353-357.

Keys, A., 1984: Serum cholesterol response to dietary cholesterol. The American Journal of Clinical Nutrition 40, 351-359.

Kerver, J. M.; Park, Y.; Song, W. O., 2002: The role of eggs in american diets: health implications and benefits. In: Watson, R. R. (ed.), Eggs and Health Promotion. Blackwell Publishing, Iowa, USA. 9-18.

Kralik, G.; Gajcevic, Z.; Skrtic, Z., 2008: The effect of different oil supplementations on laying performance and fatty acid composition of egg yolk. Italian Journal of animal Science $\mathbf{7}$, 173-183.

Kritchevsky, S. B., 2004: A review of scientific research and recommendations regarding eggs. Journal of American College of Nutrition 23, 596S -600S.

Kummerow, F. A.; Kim, Y.; Hull, J.; Pollard, J.; Ilinov, P.; Drossiev D. L.; Valek, J. 1977: The influence of egg consumption on the serum cholesterol level in human subjects. The American Journal of Clinical Nutrition 30, 664-673.

Lee, A.; Griffin, B., 2006: Dietary cholesterol, eggs and coronary heart disease risk in perspective. British Nutrition Foundation Nutrition Bulletin 31, 21-27.

Luhman, C. M.; Miller, B. G.; Beitz, D. C., 1990: The effect of feeding lovastatin and colestipol on production and cholesterol content of eggs. Poultry Science 69, 852-855.

Mattson, F. H.; Erickson, B. A.; Kligman, A. M., 1972: Effect of dietary cholesterol on serum cholesterol in man. The American Journal of Clinical Nutrition 25, 589-594.

Maurice, D. V.; Lightsey, S. F.; Hsu, K. T.; Gaylord, T. G.; Reddy, R. V., 1994: Cholesterol in eggs from different species of poultry determined by capillary GLC. Food Chemistary 50, $367-372$

McNamara, D. J., 2000: The impact of egg limitations on coronary heart disease risk: do the numbers add up? Journal of the American College of Nutrition 19, 540S-548S. 
Meluzzi, A.; Sirri, F.; Giordani, G.; Franchini, A., 1995: Livelli di colesterolo e composizione acidica dell'uovo commerciale di produzione italiana. Riviera di Avicoltura 10, 65-68.

Meluzzi, A.; Sirri, F.; Manfreda, G.; Tallarico, N.; Franchini, A., 2000: Effects of dietary vitamin E on the quality of table eggs enriched with n-3 long-chain fatty acids. Poultry Science 79, 539-545.

Mennicken, L.; Spaeth, M.; Petersen, J., 2000: Breeding for modified fatty acid profile in eggs Results of a divergent selection experiment in quails. Proc. XXI World's Poultry Congress, Montreal.

Mennicken, L.; Ponsuksili, S.; Tholen, E.; Thi Kim Khang, N.; Steier, K.; Petersen, J.; Schellander, K.; Wimmers, K., 2005: Divergent selection for $\omega 3: \omega 6$ polyunsaturated fatty acid ratio in quail eggs. Archiv Tierzucht Dummerstorf 48, 527-534.

Mensink, R. P.; Aro, A.; Den Hond, E.; German, J. B.; Griffin, B. A.; Meer, H. U.; Mutanen, M.; Pannemans, D.; Stahl, W., 2003: PASSCLAIM - Diet-related cardiovascular disease. European Journal of Nutrition 42, 16-27.

Millet, S.; De Ceulaer, K.; Van paemel, M.; Raes, K.; De Smet, S.; Janssens, J. P. L., 2006: Lipid profile in eggs of Araucana hens compared with Lohmann Selected Leghorn and ISA Brown hens given diets with different fat sources. British Poultry Science 47 (3), 294-300.

Milinsk, M. C.; Murakami, A. E.; Gomes, S. T. M.; Matsushita, M.; de Souza, N. E., 2003: Fatty acid profile of egg yolk lipids from hens fed diets rich in n-3 fatty acids. Food Chemistry 83, 287-292.

Mine, Y., 2008: Egg bioscience and biotechnology. John Wiley and Sons Inc Publishing, Hoboken, New Jersey.

Nakamura, Y.; Iso, H.; Kita, Y.; Ueshima, H.; Okada, K.; Konishi, M.; Inoue, M.; Tsugane, S., 2006: Egg consumption, serum total cholesterol concentrations and coronary heart disease incidence: Japan Public Health Center-based prospective study. British Journal of Nutrition 96, 921-928.

Natoli, S.; Markovic, T.; Lim, D.; Noakes, M.; Kostner, K., 2007: Unscrambling the research: Eggs, serum cholesterol and coronary heart disease. Nutrition \& Dietetics 64, 105-111.

Noble, R. C.; Cocchi, M., 1990: Lipid metabolism and the neonatal chicken. Progress in Lipid Research 29, 107-140. 
Noble, R. C.; Speake, B. H.; McCartney, R.; Foggin, C. M.; Deeming, D. C., 1996: Lipid composition of egg yolks derived from wild and farmed environments. Proceedings Int. Conf. "Improving our understanding of ratites a farming environment". Manchester (UK), pp. 128-129.

NRC, 1994: Nutrient Requirements of Domestic Animals. Nutrient Requirements of Poultry. 9th edn. National Academic Press, Washington, DC.

Oh, S. Y.; Miller, L. T.; 1985: Effect of dietary egg on variability of plasma cholesterol levels and lipoprotein cholesterol. The Amrican Journal of Clinical Nutrition 42, 421-431.

Oliveira, D. D.; Baiao, N. C.; Cançado, S. V.; Grimaldi, R.; Souza, M. R.; Lara, L. J. C.; Lana, A. M. Q., 2010: Effects of lipid sources in the diet of laying hens on the fatty acid profiles of egg yolks. Poultry Science 89, 2484-2490.

Reiner, G.; Dorau, H. P.; Dzapo V., 1995: Cholesterol content, nutrients and fatty acid profiles of ostrich (Struthio camelus) eggs. Archiv Fur Geflügelkunde 59, 65-68.

SAS Institute, 1986: SAS/STAT® User's Guide, release 6.03 edition. SAS institute Inc., Statistics. SAS Institute Inc., Cary, NC, USA.

Scheideler, S. E.; Jaroni, D.; Froning. G., 1998: Strain and age effects on egg composition from hens fed diets rich in n-3 fatty acids. Poultry Science 77, 192-196.

Schnohr, P.; Thomsen, O.; Riis Hansen, P.; Bobergans, G.; Lawaetz, H.; Weeke, T., 1994: Egg consumption and high-density lipoprotein cholesterol. Journal of Internal Medicine 235, 249-251.

Speake, B. K.; Surai, P. F.; Noble, R. C.; Beer, J. V.; Wood, N. A. R., 1999: Differences in egg lipid and antioxidant composition between wild and captive pheasants and geese. Comparative Biochemistry and Physiology Part B 124, 101-107.

Steel, R. G. D.; Torrie, J. H., 1960: Principles and Procedures of Statistics. McGraw-Hill, New York.

Steinhilber, S. H., 2005: Influence of strain and age of hen and dietary fat on the incorporation of omega-3-fatty acids into chicken eggs and on egg quality parameters. Archiv für Geflügelkunde 69(2), S94-S95. 
Surai, P. F.; Speake, B. K.; Noble, R. C.; Mezes, M., 1999: Species-specific differences in the fatty acid profiles of the lipids of the yolk and of the liver of the chick. Journal of the Science of Food and Agriculture 79, 733-736.

Vaghefi, S. B., 2002: Eggs and health: myths and misconceptions. In: Watson, R. R. (ed.), Eggs and Health Promotion. Blackwell Publishing, Iowa, USA. 83-100.

Vorster, H. H.; Bernade, A. J.; Barnard, H. C.; Locke, M. L.; Silvis, N.; Venter, C. S.; Smuts, S. M.; Endelbrecht, G. P.; Marais, M. P., 1992: Egg intake does not change plasma lipoprotein and coagulation profiles. The Amrican Journal of Clinical Nutrition 55, 400-410.

Warnick, G. R.; Benderson, J.; Albers, J. J., 1982: Dextran sulfate- $\mathrm{Mg}^{2+}$ precipitation procedure for quantitation of high-density-lipoprotein cholesterol. Clinical Chemistry 28, 1379-1388.

Washburn, K. W., 1990: Genetic variation in egg composition. In: Crawford R. D., (ed.), Poultry Breeding and Genetics. Elsevier, Amsterdam, 781-804.

Weggemans, R. M.; Zock, P. L.; Katan, M. B., 2001: Dietary cholesterol from eggs increases the ratio of total cholesterol to high-density lipoprotein cholesterol in humans: a meta-analysis. American Journal of Clinical Nutrition 73, 885-91.

Zanni, E. E.; Zannis, V. I.; Blum, C. B.; Herbert, P. N.; Breslow J. L., 1987: Effect of egg cholesterol and dietary fats on plasma lipids, lipoproteins, and apoproteins of normal women consuming natural diets. The Journal of Lipid Research 28, 518-527.

\section{Table 1}

Composition and nutrient content of the experimental ration (\%)

\begin{tabular}{llllll}
\hline Ingredient $(\%)$ & Chicken & Quail & Goose & Turkey & Ostrich \\
\hline Corn & 61.13 & 56.4 & 60 & 60.22 & 24.96 \\
Soy bean meal & 18.35 & 30.91 & 16.8 & 13.6 & 13.6 \\
Sunflower meal & - & - & - & - & 12.32 \\
Wheat & 10 & 5 & 11 & 12.12 & - \\
Wheat bran & - & - & - & - & 17 \\
Alfalfa & 1 & - & 5.29 & 7.1 & 23.14 \\
Salt & 0.15 & 0.15 & 0.15 & 0.15 & 0.43 \\
Di calcium phosphate & 0.73 & 1.07 & 0.98 & 1.23 & 1.37 \\
Min+vit. premix ${ }^{1}$ & 1 & 1 & 1 & 1 & 1 \\
Dl-methionine & 0.06 & 0.12 & - & - & 0.25 \\
Oyster shell & 7.58 & 5.35 & 4.78 & 4.58 & 5.93 \\
Calculated analysis & $* * * * *$ & $* * * * *$ & $* * * * *$ & $* * * * *$ & $* * * * *$ \\
ME(kcal/kg) & 2800 & 2730 & 2800 & 2800 & 2600 \\
Crude protein(\%) & 14.48 & 18.96 & 14.49 & 13.52 & 16 \\
Lysine(\%) & 0.7 & 0.99 & 0.74 & 0.69 & 0.7
\end{tabular}




\begin{tabular}{|c|c|c|c|c|c|}
\hline Methionine $(\%)$ & 0.3 & 0.42 & 0.24 & 0.23 & - \\
\hline Methionine+cyste $(\%)$ & 0.56 & 0.74 & 0.51 & 0.49 & 0.5 \\
\hline $\mathrm{Ca}(\%)$ & 3.13 & 2.37 & 2.17 & 2.17 & 3 \\
\hline $\mathrm{P} \%$ (nonphytate) & 0.24 & 0.33 & 0.29 & 0.33 & 0.5 \\
\hline Linoleic acid & 1.45 & 1.36 & 1.4 & 1.4 & 1.3 \\
\hline $\mathrm{Na}$ & 0.14 & 0.14 & 0.14 & 0.14 & 0.22 \\
\hline Determined fatty acid ${ }^{2,3}$ & $* * * * *$ & $* * * * *$ & $* * * * *$ & $* * * * *$ & $* * * * *$ \\
\hline$\Sigma$ SFA & 13.77 & 12.36 & 14.82 & 15.46 & 14.76 \\
\hline$\Sigma \mathrm{MUFA}$ & 29.56 & 33.67 & 31.29 & 31.09 & 30.65 \\
\hline ¿PUFAs & 56.64 & 53.87 & 53.98 & 53.40 & 54.49 \\
\hline$n-6$ & 53.87 & 51.41 & 51.39 & 50.91 & 51.84 \\
\hline$n-3$ & 2.77 & 2.46 & 2.59 & 2.51 & 2.64 \\
\hline$n-6 / n-3$ & 19.44 & 20.89 & 19.84 & 20.28 & 19.63 \\
\hline
\end{tabular}

${ }^{1} 2.5 \mathrm{~kg}$ of vitamin mineral premix contain: vitamin A, 6,000,000 IU; cholecalciferol, 1,500,000 IU; vitamin E (dl-alpha-tocopherol acetate), $150 \mathrm{mg}$; riboflavin, 3,000 mg; pantothenic acid, 7,000 mg; nicotinic acid, 25,000 mg; folic acid, $500 \mathrm{mg}$; choline chloride, $125000 \mathrm{mg}$ and vitamin B12, 15,000 $\mu \mathrm{g}$; Mn, 120,000 mg; Zn, 80,000 mg; Fe, 90,000 mg; Cu, 15,000 mg; I, $1,600 \mathrm{mg}$; Se, $500 \mathrm{mg}$; and Co, $600 \mathrm{mg}$.

vitamin mineral premix per ton of ostrich diet: vitamin A, 15,000,000 IU; cholecalciferol, 25,000,000 IU; vitamin E (dl-alpha-tocopherol acetate), $150 \mathrm{mg}$; vitamin $\mathrm{K} 3,3,000 \mathrm{mg}$; vitamin B1, 2,000 mg; riboflavin, 8,000 mg; pantothenic acid, 18,000 mg; nicotinic acid, 45,000 mg; folic acid, $100 \mathrm{mg}$; choline chloride, $500000 \mathrm{mg}$; Biotin, $100 \mathrm{mg}$ and vitamin B12, 100, mg; MG, 40,000 mg; Mn, 120,000 mg; Zn, 90,000 mg; Fe, 35,000 mg; Cu, 15,000 mg; I, 1,000 mg; Se, $300 \mathrm{mg}$; and Co, $100 \mathrm{mg}$ (Cilliers et al., 1997).

${ }^{2}$ The values presented are means of triplicate determinations.

${ }^{3} \Sigma$ SFA=total saturated fatty acids; $\Sigma$ MUFA=total monounsaturated fatty acids; $\Sigma$ PUFA=total polyunsaturated fatty acids. 


\section{Table 2}

Fatty acid composition of eggs $(\%)^{1}$.

Experimental diet

\begin{tabular}{|c|c|c|c|c|c|c|c|c|}
\hline \multirow{2}{*}{\multicolumn{2}{|c|}{ tty acid² }} & & & & & & & \\
\hline & & Chicken & Quail & Goose & Turkey & Ostrich & $\mathrm{SEM}^{3}$ & $\mathrm{P}$ \\
\hline$: 0$ & Myristic & 0.55 & 0.63 & 0.68 & 0.65 & 0.612 & 0.024 & - \\
\hline 0 & Palmitic & $29.31^{\mathrm{b}}$ & $30.40^{\mathrm{b}}$ & $32.34^{\mathrm{a}}$ & $30.92^{\mathrm{b}}$ & $23.17^{\mathrm{c}}$ & 0.475 & $* *$ \\
\hline :0 & Stearic & $10.51^{\mathrm{a}}$ & $8.98^{\mathrm{b}}$ & $8.28^{\mathrm{b}}$ & $8.97^{\mathrm{b}}$ & $10.13^{\mathrm{a}}$ & 0.225 & $*$ \\
\hline $8: 1 n-9$ & Oleic & $42.61^{\mathrm{b}}$ & $41.62^{\mathrm{b}}$ & $41.57^{\mathrm{b}}$ & $41.50^{\mathrm{b}}$ & $44.20^{\mathrm{a}}$ & 0.567 & $* *$ \\
\hline $8: 1 n-7$ & Vaccenic & $1.02^{\mathrm{b}}$ & $2.43^{\mathrm{b}}$ & $2.01^{\mathrm{b}}$ & $3.01^{\mathrm{a}}$ & $2.05^{\mathrm{b}}$ & 0.031 & $*$ \\
\hline $8: 2 n-6$ & Linoleic & $13.65^{\mathrm{ab}}$ & $12.80^{\mathrm{b}}$ & $11.61^{\mathrm{b}}$ & $12.35^{\mathrm{b}}$ & $14.16^{\mathrm{a}}$ & 0.328 & $* *$ \\
\hline $8: 3 n-3$ & Linolenic & $0.29^{\mathrm{b}}$ & $0.31^{\mathrm{b}}$ & $0.45^{\mathrm{b}}$ & $0.32^{\mathrm{b}}$ & $1.01^{\mathrm{a}}$ & 0.036 & $*$ \\
\hline $0: 4 n-6$ & Arachidonic & $1.51^{\mathrm{c}}$ & $1.41^{\mathrm{c}}$ & $2.45^{\mathrm{b}}$ & $1.32^{\mathrm{c}}$ & $4.37^{\mathrm{a}}$ & 0.046 & $*$ \\
\hline $0: 5 n-3$ & Eicosapentaenoic & nd & nd & 0.06 & nd & 0.05 & 0.011 & - \\
\hline $2: 5 n-3$ & Docosapentaenoic & Trace & 0.07 & 0.04 & 0.02 & 0.03 & 0.007 & - \\
\hline $2: 6 n-3$ & Docosahexaenoic & $0.54^{\mathrm{a}}$ & $0.44^{\mathrm{a}}$ & $0.35^{\mathrm{a}}$ & $0.38^{\mathrm{a}}$ & $0.02^{\mathrm{b}}$ & 0.078 & $*$ \\
\hline FA & & $40.37^{\mathrm{a}}$ & $40.01^{\mathrm{a}}$ & $41.3^{\mathrm{a}}$ & $40.54^{\mathrm{a}}$ & $33.91^{\mathrm{b}}$ & 0.321 & $*$ \\
\hline IUFA & & $43.63^{\mathrm{b}}$ & $44.05^{\mathrm{b}}$ & $43.58^{\mathrm{b}}$ & $44.51^{\mathrm{b}}$ & $46.25^{\mathrm{a}}$ & 0.412 & $*$ \\
\hline UFA & & $15.99^{\mathrm{b}}$ & $15.03^{\mathrm{b}}$ & $14.96^{\mathrm{b}}$ & $14.39^{\mathrm{b}}$ & $19.64^{\mathrm{a}}$ & 0.128 & $* *$ \\
\hline UFA n-6 & & $15.16^{\mathrm{b}}$ & $14.21^{\mathrm{b}}$ & $14.06^{\mathrm{b}}$ & $13.67^{\mathrm{b}}$ & $18.53^{\mathrm{a}}$ & 0.271 & $*$ \\
\hline UFA n-3 & & 0.83 & 0.82 & 0.9 & 0.72 & 1.11 & 0.033 & - \\
\hline :n-3 & & $18.26^{\mathrm{a}}$ & $17.33^{\mathrm{a}}$ & $15.62^{\mathrm{b}}$ & $18.98^{\mathrm{a}}$ & $16.69^{\mathrm{ab}}$ & 0.751 & $*$ \\
\hline
\end{tabular}

${ }^{\mathrm{a}, b, c}$ Values within the same row with no common superscript are different; $* \mathrm{P}<0.05$ or $* * \mathrm{P}<0.01$. ${ }^{1}$ Results expressed as a percentage of the total fatty acids. The values are presented as mean \pm S.D. of 5 observations, each one in triplicate per species.

${ }^{2} \Sigma$ SFA=total saturated fatty acids; $\Sigma$ MUFA=total monounsaturated fatty acids; $\Sigma$ PUFA=total polyunsaturated fatty acids; $\Sigma$ PUFA-n6 = C18:2n-6 + C20:4n-6; $\Sigma$ PUFA-n3 = C18:3n-3 + $\mathrm{C} 20: 5 n-3+\mathrm{C} 22: 5 n-3+\mathrm{C} 22: 6 n-3$

${ }^{3} \mathrm{SEM}=$ standard error of mean. 
$\mathrm{nd}=$ not detected . 


\section{Table 3}

Comparison of the cholesterol concentration of egg yolk ( $\mathrm{mg} \mathrm{g}^{-1}$ of yolk) from different avian species.

\begin{tabular}{llllll}
\hline & \multicolumn{2}{c}{ Weight $(\mathrm{g})$} & & Cholesterol $^{1}$ & \\
\cline { 2 - 3 } Treatment & Egg $(\mathrm{g})$ & Yolk $(\mathrm{g})$ & & $\mathrm{mg} \mathrm{g}^{-1}$ of yolk & \\
Chicken & $53 \pm 4.2$ & $14.8 \pm 2.1$ & $12.25^{\mathrm{b}}$ & \\
Quail & $9.6 \pm 0.6$ & $3.4 \pm 0.23$ & & $11.12^{\mathrm{b}}$ & within the \\
Goose & $131.5 \pm 2.01$ & $49.18 \pm 3.21$ & & $15.81^{\mathrm{a}}$ & column with \\
Turkey & $85.2 \pm 3.69$ & $25.5 \pm 1.31$ & & $13.35^{\mathrm{ab}}$ & superscript \\
Ostrich & $1330.5 \pm 62.2$ & $314.45 \pm 34.1$ & & $9.75^{\mathrm{c}}$ &
\end{tabular}

$\begin{array}{llll}\text { SEM }^{2} & - & - & 0.18 \\ \mathrm{P} & - & - & *\end{array}$

significantly; $* \mathrm{P}<0.05$

${ }^{1}$ The values are presented as mean \pm S.D. of 10 different individuals' observations, each one in triplicate per species.

${ }^{2} \mathrm{SEM}=$ standard error of mean. 


\section{Table 4}

Comparison of plasma lipid concentration between before and after ingestion of different avian species one fresh egg per day in healthy adult men ${ }^{1}$.

\begin{tabular}{llllll}
\hline & \multicolumn{5}{c}{ Item $\left(\mathrm{mg} \mathrm{d}^{-1}\right)$} \\
Treatments & TC & TG & LDL-C & HDL-C & LDL-C:HDL-C \\
\hline CHICKEN & & & & & \\
Before & $185.00 \pm 1.59$ & $85.55 \pm 1.14$ & $114.30 \pm 1.94^{\mathrm{b}}$ & $53.58 \pm 0.50^{\mathrm{a}}$ & $2.13 \pm 0.05$ \\
After & $186.83 \pm 1.05$ & $84.89 \pm 1.21$ & $117.25 \pm 1.31^{\mathrm{a}}$ & $52.59 \pm 0.51^{\mathrm{b}}$ & $2.22 \pm 0.04$ \\
QUAIL & & & & & \\
Before & $183.55 \pm 1.76$ & $86.45 \pm 0.45$ & $109.47 \pm 3.07^{\mathrm{b}}$ & $56.78 \pm 1.49$ & $1.92 \pm 0.10$ \\
After & $185.78 \pm 0.83$ & $85.58 \pm 3.73$ & $114.21 \pm 1.48^{\mathrm{a}}$ & $54.44 \pm 2.03$ & $2.10 \pm 0.10$ \\
GOOSE & & & & & \\
Before & $183.81 \pm 1.33$ & $86.19 \pm 1.29$ & $112.76 \pm 1.96^{\mathrm{b}}$ & $53.80 \pm 0.81$ & $2.09 \pm 0.06^{\mathrm{b}}$ \\
After & $187.00 \pm 1.13$ & $86.85 \pm 0.77$ & $118.145 \pm 2.27^{\mathrm{a}}$ & $51.49 \pm 1.91$ & $2.29 \pm 0.12^{\mathrm{a}}$ \\
TURKEY & & & & & \\
Before & $183.96 \pm 2.75$ & $83.76 \pm 0.56$ & $110.08 \pm 4.14^{\mathrm{b}}$ & $57.12 \pm 2.41$ & $1.93 \pm 0.14^{\mathrm{b}}$ \\
After & $187.45 \pm 1.56$ & $84.61 \pm 0.71$ & $116.81 \pm 1.09^{\mathrm{a}}$ & $53.71 \pm 1.64$ & $2.17 \pm 0.09^{\mathrm{a}}$ \\
OSTRICH & & & & & \\
Before & $186.01 \pm 0.99$ & $86.88 \pm 1.26$ & $109.19 \pm 0.77^{\mathrm{b}}$ & $59.44 \pm 0.73^{\mathrm{a}}$ & $1.84 \pm 0.03$ \\
After & $186.53 \pm 0.69$ & $87.65 \pm 1.24$ & $114.01 \pm 1.43^{\mathrm{a}}$ & $54.98 \pm 1.43^{\mathrm{b}}$ & $2.08 \pm 0.20$ \\
\hline & & & & &
\end{tabular}

\footnotetext{
${ }^{1}$ Values are means \pm SD

${ }^{2} \mathrm{TC}=$ Total cholesterol; $\mathrm{TG}=$ Triglycerides $;$ HDL-C $=$ High density lipoprotein cholesterol; LDL$\mathrm{C}=$ Low density lipoprotein cholesterol.

${ }^{\mathrm{a}, \mathrm{b}}$ Values within the same column with no common superscript are different significantly; $\mathrm{P}<0.05$.
} 


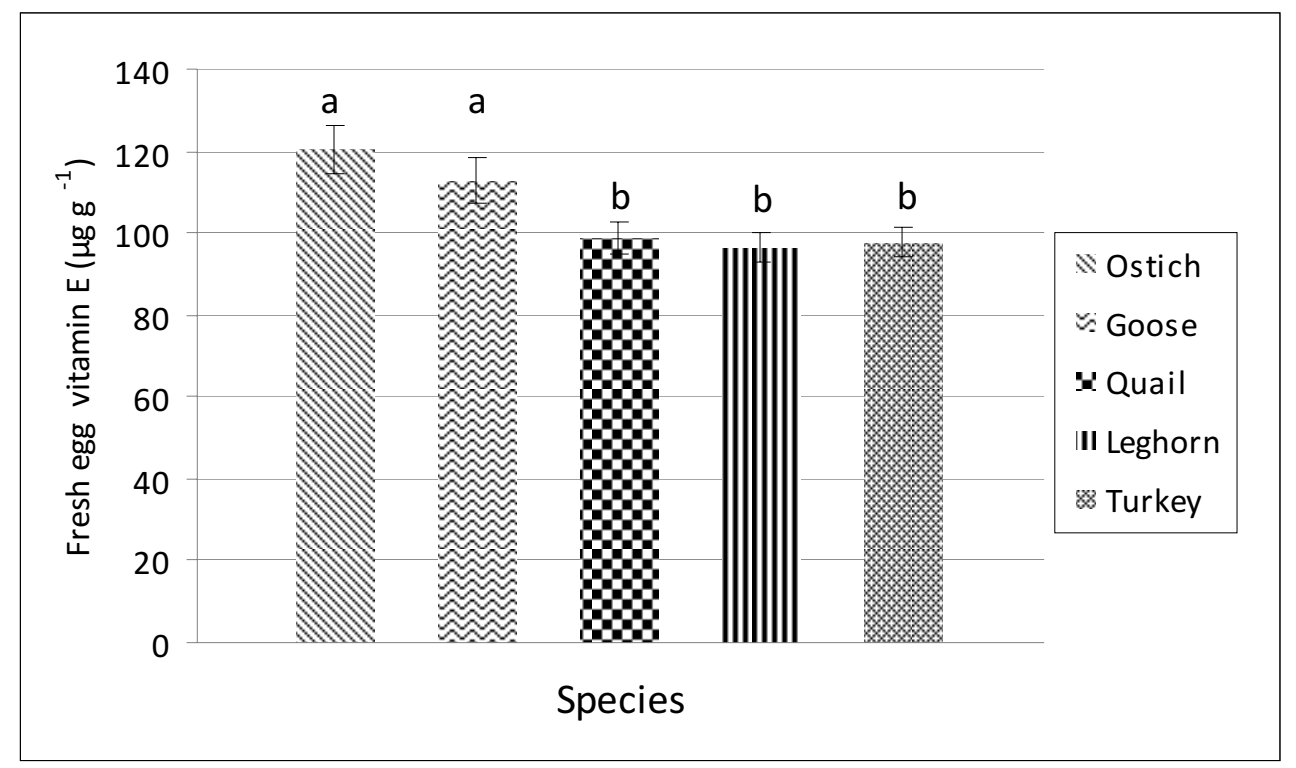

Figure 1. VitE ( $\mu \mathrm{g} \mathrm{g}^{-1}$ of yolk) contents of fresh egg from different avian species; $(\mathrm{p}<0.05)$

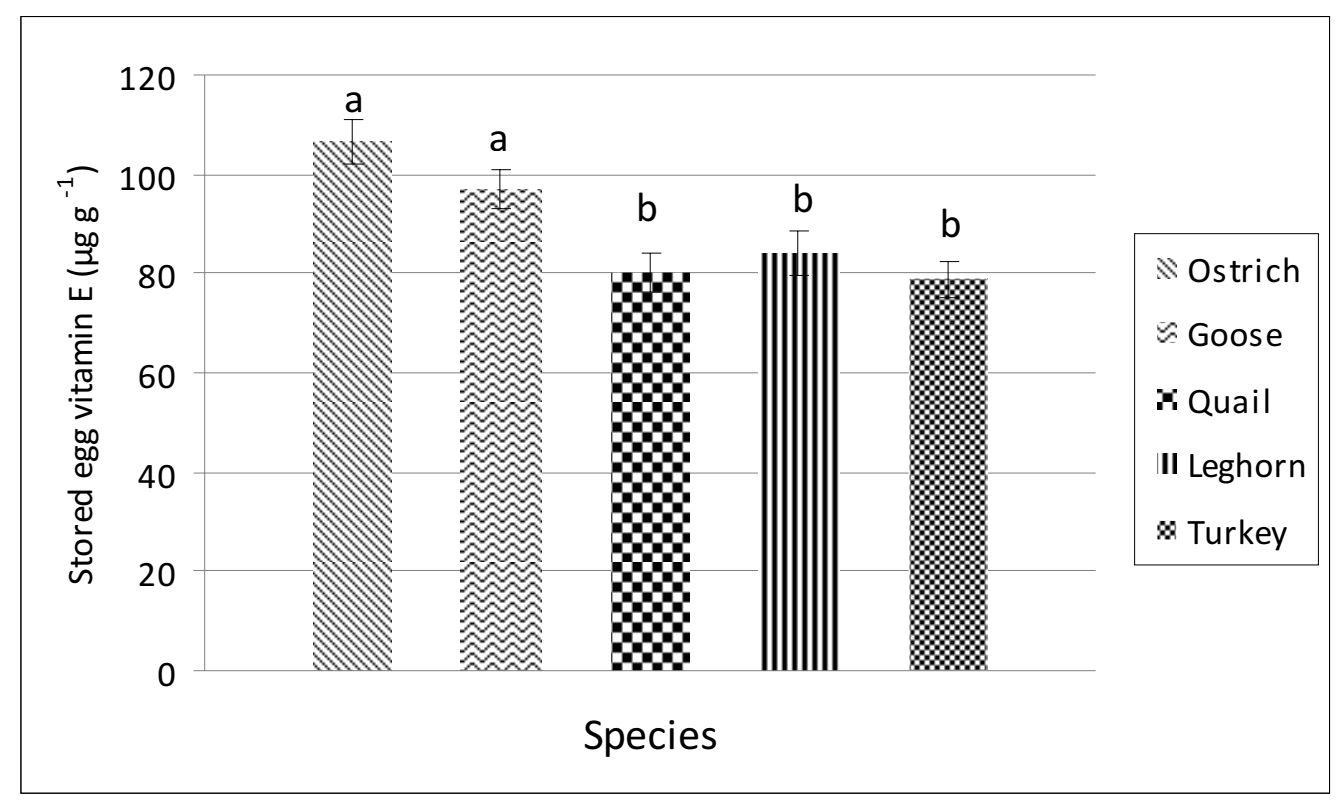

Figure 2. VitE ( $\mu \mathrm{g} \mathrm{g}^{-1}$ of yolk) contents of stored egg from different avian species; $(\mathrm{p}<0.01)$ 